\title{
Leydig cell tumors of the testis: A molecular-cytogenetic study based on a large series of patients
}

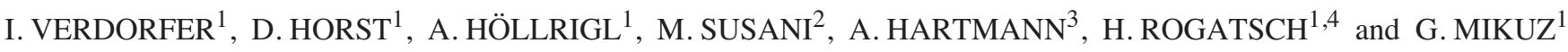 \\ ${ }^{1}$ Institute of Pathology, Medical University of Innsbruck, A-6020 Innsbruck; ${ }^{2}$ Department of Clinical Pathology, Medical \\ University of Vienna, AKH, A-1090 Vienna, Austria; ${ }^{3}$ Institute of Pathology, University of Regensburg, D-93053 \\ Regensburg, Germany; ${ }^{4}$ Institute of Pathology, LKH Klagenfurt, A-9020 Klagenfurt, Austria
}

Received October 2, 2006; Accepted November 6, 2006

\begin{abstract}
The genetic features of the uncommon Leydig cell tumors (LCT) are largely unknown. Consequently, it is of great importance to elucidate the pathogenesis of testicular germ cell tumors by cytogenetic and molecular biological investigations. The purpose of the present study was the examination of cytogenetic features of these tumors in a large series of LCT. It comprised formalin-fixed, paraffin-embedded tissue samples from 25 LCT to analyze the chromosomal constitution using comparative genomic hybridization (CGH). In most of the studied cases, the aberrant cell population was additionally defined by interphase fluorescence in situ hybridization (I-FISH). Our molecular-cytogenetic study indicates chromosomal imbalances in the majority of our cases $(21 / 25$, $84 \%)$. The most frequent findings were gain of chromosome $\mathrm{X}, 19$ or $19 \mathrm{p}$ and loss on chromosome 8 and 16 .
\end{abstract}

\section{Introduction}

Leydig cell tumors (LCT) of the testis represent only 1-3\% of testicular neoplasms. These tumors occur over a wide range of age, from childhood to senior adulthood. They are most common in the third to sixth decade, approximately one fourth of the reported cases occurred before puberty. LCT are always benign in children and in $90 \%$ of adults $(1,2)$. The presenting features are painless testicular enlargement, gynecomastia (seen in $30 \%$ of adult patients and in $10 \%$ of children with virilization) and sexual dysfunction (3). Generally, the tumors are sporadic, although a familial occurrence in a father and his son has been reported (4). Occasionally, LCT are seen in patients with Klinefelter syndrome (5) and about 5-10\% of patients have a history of cryptorchisms (6).

Correspondence to: Dr Irmgard Verdorfer, Institute of Pathology, Medical University of Innsbruck, Muellerstrasse 44, A-6020 Innsbruck, Austria

E-mail: irmgard.verdorfer@i-med.ac.at

Key words: Leydig cell tumors, sex-cord stromal tumors, comparative genomic hybridization, fluorescence in situ hybridization
Immunostaining for vimentin, inhibin, Melan A and calretinin is positive in over $90 \%$ of the cases and negative for PLAP (placental alkaline phosphatase) and cytokeratin $(7,8)$.

The genetic features of these uncommon tumors are largely unknown. $\mathrm{CGH}$ is a suitable method to give an in vivo genomic overview of these uncommon tumors, which can achieve practical importance in diagnosis and prognosis.

DNA ploidy assessments and cellular proliferation augment established prognostic factors in predicting malignancy. Aneuploidy is more frequently seen in malignant than in benign LCT (8-11). Whereas the histomorphology of these tumors are well described, no reports are available in the literature of cytogenetic data. The objective of this study was to characterize the genetic alterations of a large LCT series and to correlate these results with clinicopathologic data.

\section{Materials and methods}

Tumor specimens and immunohistochemistry. Twenty-five cases coded as LCT of the testis from 1981 to 2004 were retrieved from the Institute of Pathology Innsbruck, Austria; Institute of Pathology Regensburg, Germany and the Department of Clinical Pathology Vienna, Austria.

Tissue sections were stained with haematoxylin and eosin, profiled immunohistochemically with antibodies against vimentin, cytokeratin, $\alpha$-inhibin, Melan A, chromogranin, synaptophysin, AFP ( $\alpha$-fetoprotein), CD138, PLAP (placental alcaline phosphatase) and $\mathrm{B}-\mathrm{HCG}$ (beta human chorionic gonadotropin. Immunohistochemistry was performed using an automated immunostainer (Nexes, Ventana, Tucson, AZ, USA). The tumors are classified according to the WHO classification of testicular tumors (12). All 25 analyzed LCT were non-metastasizing tumors, which were diagnosed at a mean age of 42.2 years (range, 4-69 years). Two tumors in this study were diagnosed as malignant.

Comparative genomic hybridization (CGH). DNA from paraffin-embedded tumor material was extracted according to standard protocols. CGH technique that has been described previously in detail was applied (13). Briefly, tumor- and reference-DNA was labeled by nick translation with either biotin or digoxigenin (Roche Diagnostics, Mannheim, Germany). After co-precipitation with human Cot-1 DNA 
Table I. Summary of clinical, histology and immunohistochemical data in 25 Leydig cell tumors of the testis.

\begin{tabular}{|c|c|c|c|c|}
\hline No. & Localization & $\begin{array}{l}\text { Vascular invation/ } \\
\text { tumor behavior }\end{array}$ & Age & Immunohistochemical data \\
\hline 1 & Testis $r$ & No/benign & 44 & $\begin{array}{l}\text { Positive for vimentin; negative for cytokeratin, chromo- } \\
\text { granin and synaptophysin }\end{array}$ \\
\hline 2 & Testis $r$ & No/benign & 35 & - \\
\hline 3 & Testis 1 & No/benign & 57 & - \\
\hline 4 & Testis 1 & No/benign & 23 & - \\
\hline 5 & Testis & No/benign & 38 & - \\
\hline 6 & Testis 1 & No/benign & 50 & - \\
\hline 7 & Testis $r$ & No/benign & 38 & - \\
\hline 8 & Testis $r$ & No/benign & 64 & Positive for inhibin; Ki-67 activity $<5 \%$ \\
\hline 9 & Testis & $\begin{array}{l}\text { Yes/malign tumor size } \\
>5 \mathrm{~cm} \text { polymorph cells }\end{array}$ & 55 & - \\
\hline 10 & Testis & No/benign & 40 & - \\
\hline 11 & Testis $\mathrm{r}$ & No/benign & 23 & - \\
\hline 12 & Testis $r$ & No/benign & 29 & $\begin{array}{l}\text { Positive for vimentin, negative for cytokeratin; MIB- } 1 \\
\text { activity }<0.5 \%\end{array}$ \\
\hline 13 & Testis 1 & No/benign & 28 & $\begin{array}{l}\text { Positive for vimentin; negative for cytokeratin, PLAP and } \\
\text { ß-HCG; MIB-1 activity } 1-2 \%\end{array}$ \\
\hline 14 & Testis $r$ & No/benign & 62 & Negative for AFP, $\beta$-HCG and CD138 MIB-1 activity $\sim 1 \%$ \\
\hline 15 & Testis $r$ & No/benign & 36 & $\begin{array}{l}\text { Positive for vimentin, weak positive for Melan A; negative } \\
\text { for PLAP and cytokeratin; MIB-1 activity }<1 \%\end{array}$ \\
\hline 16 & Testis $r$ & No/benign & 4 & - \\
\hline 17 & Testis & No/benign & 69 & - \\
\hline 18 & Testis 1 & No/benign & 35 & - \\
\hline 19 & Testis & No/benign & 60 & - \\
\hline 20 & Testis $r$ & No/benign & 24 & - \\
\hline 21 & Testis 1 & No/benign & 36 & Positive for inhibin, focal positive AFP and CAM $5.2(<5 \%)$ \\
\hline 22 & Testis 1 & No/benign & 62 & - \\
\hline 23 & Testis 1 & No/benign & 24 & - \\
\hline 24 & Testis 1 & No/benign & 53 & - \\
\hline 25 & Testis I & $\begin{array}{l}\text { Yes/malign tumor size } \\
4.8 \mathrm{~cm} \mathrm{1/10} \mathrm{HPF}\end{array}$ & 66 & $\begin{array}{l}\text { Positive for vimentin, calretinin and Melan A; negative for } \\
\text { AFP, PLAP B-HCG and chromogranin and synaptophysin } \\
\text { MIB-1 activity } 5 \%\end{array}$ \\
\hline
\end{tabular}

Testis $r$, testis right; testis 1, testis left; PLAP, placental alcaline phosphatase; AFP, $\alpha$-fetoprotein; B-HCG, human chorionic gonadotropin; HPF, high power fields; bold type, malignant cases.

hybridization was carried out in normal human metaphase cells for 3 days at $37^{\circ} \mathrm{C}$. For detection, the slides were stained with avidin-fluorescein isothiocyanate (Vector Labs Burlingame, CA) and anti-digoxigenin-rhodamine (Roche Diagnostics). Evaluation of the $\mathrm{CGH}$ preparations was performed using a fluorescence microscope (Zeiss Axioplan) equipped with a CCD camera (JAI M300) and the ISIS software (Metasystems, Altlussheim. Germany). Gains or losses were calculated as significant by the evaluation software with fluorescence ratio borderline values of 0.8 and 1.25 , respectively. Pericentromeric, heterochromatic regions, telomeric regions and chromosome $\mathrm{Y}$ were excluded from the evaluation.
Interphase-fluorescence in situ hybridization (FISH). Parallel interphase-FISH was applied to define the involvement of copy number changes and for estimating the size of the aberrant cell population. Slide and probe preparation were performed according to the protocol of the manufacturer (Vysis Inc., Downers Grove, IL, USA). DNA probes for the centromeric region for chromosome $\mathrm{X} / \mathrm{Y}, 2,3,8,16$ and 17 , a locus specific probe for LSI 13q14 and a telomeric probe for chromosomes $19 \mathrm{p}$ were used.

\section{Results}

Twenty-five non-metastasizing tumor specimens from male patients were analyzed in this study. The histopathological, 

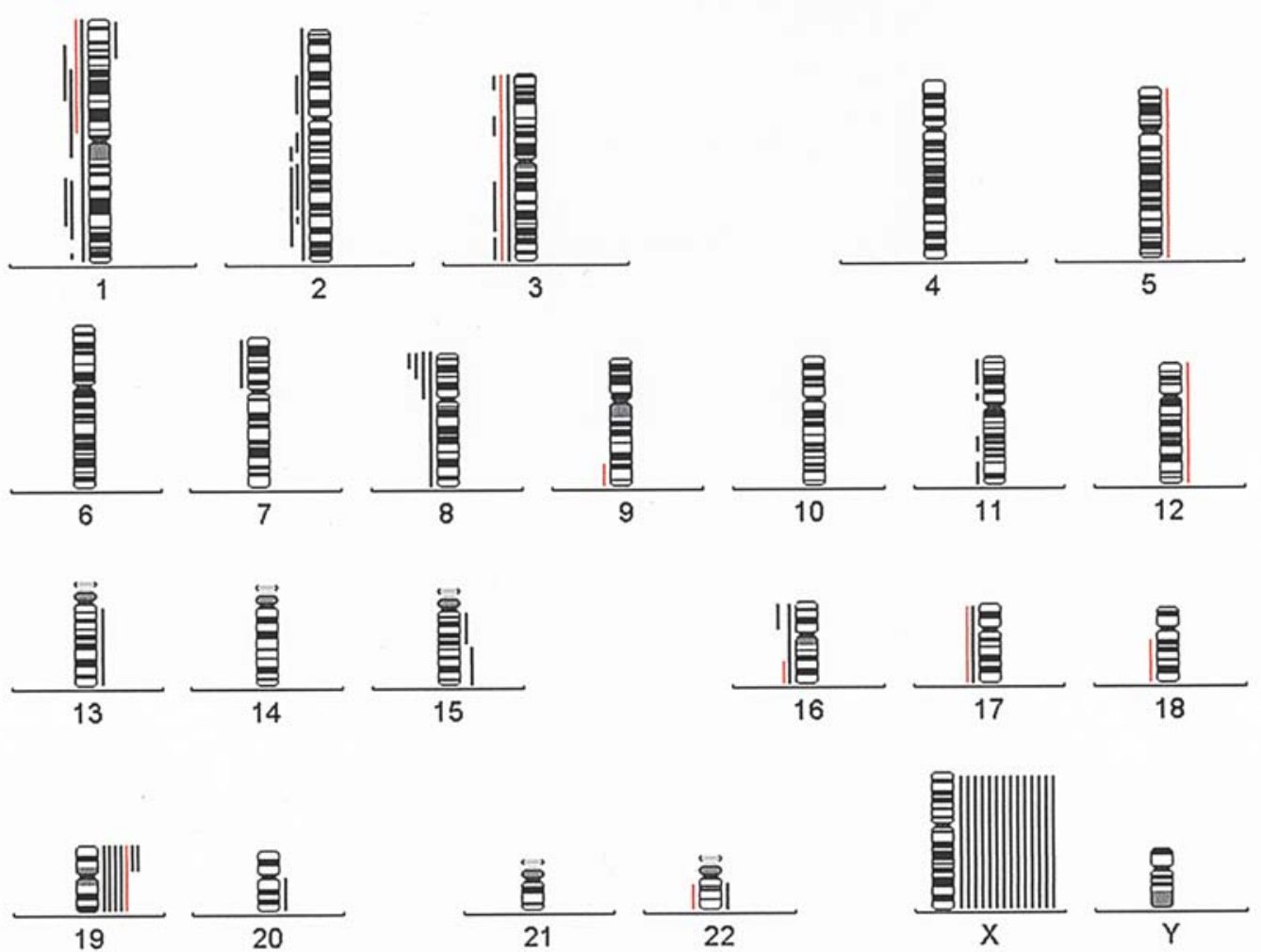

Figure 1. Summary of chromosomal imbalances detected by CGH in 21 Leydig cell tumors: vertical lines on the right side of the ideogram indicate gain, and those on the left loss of genetic material. Each line represents gain or loss in a single case; DNA copy number changes in our malignant tumors (case 9 is indicated as orange lines and case 25 as blue lines).

immunohistochemical and CGH findings were investigated.

The immunohistochemical analyses showed positive staining for vimentin and $\alpha$-inhibin, and negative staining for cytokeratin, chromogranin, PLAP, AFP and B-HCG. A summary of available clinical, histology and immunohistochemical data is given in Table I. The majority of the analyzed LCT showed chromosomal imbalances $(21 / 25,84 \%)$. The total number of DNA imbalances per tumor varied from case to case. Overall, 55 DNA imbalances were detected with a mean of 2.08 per case. Gains and losses were approximately equal with a gain/loss ratio of 1.26:1 (29 gains vs 26 losses).

A high genetic heterogeneity and involvement of chromosomes were found. Gain on chromosome $X$ was detected at a high frequency (56\%), followed by gain of chromosome 19 or $19 \mathrm{p}$ in $28 \%$ and losses on material of chromosome 1 $(24 \%)$ and 8 or $8 p$ in $16 \%$. Chromosomal location of DNA gains and losses is given in Table I and Fig. 1.

\section{Discussion}

Genetic data on LCT in the literature are rare due the low incidence of these tumors. Only few mutation analyses in LCT are reported in the literature $(14,15)$. Mutations of the luteinizing hormone receptor gene, located on 2 p21 are known $(16,17)$. To our knowledge, no cytogenetic data are available of LCT in the literature. This study is the first report on chromosomal aberrations in a series of LCT. The majority of DNA imbalances in our study were gains and losses of entire chromosomes, indicating missegregation of chromo- somes as main mechanisms for producing aberrations in LCT.

Sex chromosomes, especially chromosome $\mathrm{X}$ seems to play an import role in oncogenesis of testicular germ cell tumors $(18,19)$ and in LCT $(20)$. The frequent finding of gain of chromosome $\mathrm{X}$ by $\mathrm{CGH}$ in the present study was confirmed by FISH, with mainly two copies of chromosome X, showing $\mathrm{XXY} / \mathrm{XX} / \mathrm{XXY}$ or XXY/XXYY mosaicism (Table II). The distribution of the sex chromosomes in the present study suggests a heterogeneous population of near-diploid to neartetraploid cells. The fact that in $56 \%$ of our cases of LCT showed gain on chromosome $\mathrm{X}$ is of interest, because overexpression of chromosome $\mathrm{X}$ was also a frequent observation in seminomas, non-seminomas and spermatocytic seminomas (21-23). The biological and clinical significance of numerical increase in $\mathrm{X}$ chromosomes in testicular germ cell tumors was suggested by enhanced expression of the $2 \mathrm{X}$-linked oncogenes ARAF1 and EKL1 (24).

Gain of chromosome 19 or $19 \mathrm{p}$ was observed as the second common aberration in this study, usually involving the entire chromosome (Fig. 1). Gain of chromosome 19 is reported in several other tumors $(25,26)$, however, the gain of chromosome 19 should be interpreted with caution since chromosome 19 is prone to hybridization variability that may result in $\mathrm{CGH}$ artefacts. In three cases, we were able to carry out a successful FISH analysis with telomeric probes for 19p. In two of these cases the CGH result was confirmed by FISH.

Approximately $10 \%$ of LCT are malignant and metastases occur usually within 2 years after the initial tumor diagnosis $(27,28)$. Malignant behavior in a prepubertal patient has not 
Table II. Summary of CGH and I-FISH data in 25 Leydig cell tumors of the testis.

\begin{tabular}{|c|c|c|c|}
\hline \multirow[b]{2}{*}{ No. } & \multicolumn{2}{|c|}{$\mathrm{CGH}$} & \multirow{2}{*}{$\begin{array}{c}\text { FISH } \\
\text { Losses and gains (\% nuclei, copy number) }\end{array}$} \\
\hline & Losses & Gains & \\
\hline 1 & 8pter-p21 & $\mathrm{X}$ & Gain X (33) \\
\hline 2 & None & $\mathrm{X}$ & Gain X (34) \\
\hline 3 & None & $19 \mathrm{p}, \mathrm{X}$ & Gain X (40) \\
\hline 4 & None & $\mathrm{X}$ & Gain X (33) \\
\hline 5 & $2^{\mathrm{a}}$ & $19, \mathrm{X}$ & Gain 19p (43, mainly 3-4 signals), gain X (31) \\
\hline 6 & $3^{\mathrm{a}}$ & $13,15 q 11.2-q 21.1$ & Loss 3 (66, $0-1$ copy), gain $13 q 14$ (48, mainly $3-5$ signals) \\
\hline 7 & None & 1pter-p33, 15q21.3-qter & Not done \\
\hline 8 & None & $\mathrm{X}$ & Gain X (54) \\
\hline \multirow[t]{3}{*}{9} & $1 p, 3,9 q 32-q t e r$ & $5,12,19$ & Loss $3(60,0-1$ copy $)$ \\
\hline & 16q21-qter, 17 & & Loss 17 (53, 0-1 copy) \\
\hline & $18 q, 22$ & & Gain 19p (32, mainly 3-4 signals) \\
\hline 10 & $8 \mathrm{p}$ & None & Loss 8p22 (66, 0-1 copy) \\
\hline 11 & None & None & \\
\hline 12 & None & None & \\
\hline 13 & 1p31.3-q13.3; 1q23-q42.1 & $19, X$ & Gain X (24); gain 19 not confirmed \\
\hline 14 & None & None & \\
\hline 15 & None & $\mathrm{X}$ & Gain X (20) \\
\hline 16 & None & $19,20 \mathrm{q}, 22 \mathrm{q}, \mathrm{X}$ & Gain X (18) \\
\hline 17 & $1,3,7 \mathrm{p}, 8,11^{\mathrm{a}}$ & $19 p, X$ & Loss CEP 8 (64, 1 copy), 8q24 (55, 1 copy); gain X (43) \\
\hline 18 & 8 pter-p22 & $19, \mathrm{X}$ & Gain X (16) \\
\hline 19 & $1 \mathrm{p} 34.2-\mathrm{p} 22.1,1 \mathrm{q} 23-\mathrm{q} 32.2$ & None & Not done \\
\hline 20 & $2 q^{a}$ & $\mathrm{X}$ & Gain X (35) \\
\hline 21 & 16,17 & None & Loss of 16 (79, 1 copy), loss of 17 (76, 1 copy) \\
\hline 22 & 2 & None & Loss 2 (33, 1 copy) \\
\hline 23 & None & $\mathrm{X}$ & Gain X (35) \\
\hline 24 & None & None & \\
\hline 25 & $16 \mathrm{p}$ & $\mathrm{X}$ & Gain X (26) \\
\hline
\end{tabular}

ambalance with a clear shift, but the CGH profile shows only a partially significant imbalance (partially reaching the threshold); bold type, malignant cases.

been reported (6). The features indicating malignancy are presence of tumor size $>5 \mathrm{~cm}$, excessive mitotic rates (with 3-5 mitotic figures/10 HPF), tumor necrosis, vascular invasion, anaploid DNA value, cytologic atypia, increased MIB-1 activity (>5\%) and a positive staining for $\mathrm{p} 53$ protein. Tumors that lack all these features are extremely unlikely to metastasize.

DNA ploidy status is reported as a useful prognostic indicator in these tumors $(8,10,11)$. Several studies suggest, that the majority of benign LCT are diploid and the malignant tumors aneuploid. Our malignant tumor (case 9, from a 55year-old patient) had a size $>5 \mathrm{~cm}$, vascular invasion and polymorphic cells. In this tumor the highest number of DNA alterations was found, including loss of 1p, 3, 9q32-qter, 16q21-qter, 17, 18q and 22, gains of entire chromosome 5, 12 and 19. Based on a tumor size of $4.8 \mathrm{~cm}$, vascular invasion, mitotic figures $1 / 10 \mathrm{HPF}$ and a proliferation index MIB-1 of $5 \%$, case 25 was diagnosed as malignant tumor. Loss of $16 p$ material and gain of chromosome $\mathrm{X}$ only were detected by $\mathrm{CGH}$.
The molecular cytogenetic data in this study represent a first contribution to the poorly explored entity of LCT. Regarding the heterogeneous pattern of chromosomal aberrations, the significance of genetic lesions remains unclear. In conclusion, our data focus attention on the relevance of gain of chromosome $\mathrm{X}$ in the oncogenesis of these tumors that may be the basis for further examinations.

\section{Acknowledgements}

The present case report is part of a study of Leydig cell tumors, supported by the Austrian Cancer Society/Tyrol.

\section{References}

1. Wilson BE and Netzloff ML: Primary testicular abnormalities causing precocious puberty Leydig cell tumor, Leydig cell hyperplasia and adrenal rest tumor. Ann Clin Lab Sci 13: 315-320, 1983.

2. Ponce de Leon Roca J, Algaba Arrea F, Bassas Arnau L and Villavicencio Mavrich H: Leydig cell tumor of the testis. Arch Esp Urol 53: 453-458, 2000. 
3. Papatsoris AG, Triantafyllidis A, Gekas A, Karamouzis MV and Rosenbaum T: Leydig cell tumor of the testis. New cases and review of the current literature. Tumori 90: 422-423, 2004.

4. Bokemeyer C, Kuczyk M, Schoffski P and Schmoll JH: Familial occurrence of Leydig cell tumors: a report of a case in a father and his adult son. J Urol 150: 1509-1510, 1993.

5. Ulbright TM, Amin MB and Young RH: Tumors of the testis, adnexa, spermatic cord and scrotum. In: AFIP Atlas of Tumor Pathology. 3rd Series, Fascicle 25, Washington DC, 1999.

6. Kim I, Young RH and Scully RE: Leydig cell tumors of the testis. A clinicopathological analysis of 40 cases and review of the literature. Am J Surg Pathol 9: 177-192, 1985.

7. Augusto D, Leteurtre E, De La Taille A, Gosselin B and Leroy X: Calretinin: a valuable marker of normal and neoplastic Leydig cells of the testis. Appl Immunohistochem Mol Morphol 10: 159-162, 2002.

8. Cheville JC, Sebo TJ, Lager DJ, Bostwick DG and Farrow GM: Leydig cell tumor of the testis: a clinicopathologic, DNA content and MIB-1 comparison of nonmetastasizing and metastasizing tumors. Am J Surg Pathol 22: 1361-1367, 1998.

9. Padberg BC, Lauritzen I, Achilles E, Holl K, Bressel M, Kloppel G, Dralle H and Schroder S: DNA cytophotometry in adrenocortical tumours: a clinicomorphological study of 66 cases. Virchows Arch A Pathol Anat Histopathol 419: 167-170, 1991.

10. Palazzo JP, Petersen RO, Young RH and Scully RE: Deoxyribonucleic acid flow cytometry of testicular Leydig cell tumors. J Urol 152: 415-417, 1994.

11. McCluggage WG, Shanks JH, Arthur K and Banerjee SS: Cellular proliferation and nuclear ploidy assessments augment established prognostic factors in predicting malignancy in testicular Leydig cell tumours. Histopathology 33: 361-368, 1998.

12. Sesterhenn IA, Cheville J, Wooward PJ, Damjanov I, Jacobsen GK, Nistal M, Paniagua R and Renshaw AA: Germ cell tumours. In: Pathology and Genetics: Tumours of the Urinary System and Male Genital Organs. Eble JN, Sauter G, Epstein JI and Sesterhenn IA (eds). IARC Press, Lyon, pp251-258, 2004.

13. Wolff E, Liehr T, Vorderwulbecke U, Tulusan AH, Husslein EM and Gebhart E: Frequent gains and losses of specific chromosome segments in human ovarian carcinomas shown by comparative genomic hybridization. Int J Oncol 11: 19-23, 1997.

14. Hirakawa T and Ascoli M: A constitutively active somatic mutation of the human lutropin receptor found in Leydig cell tumors activates the same families of $\mathrm{G}$ proteins as germ line mutations associated with Leydig cell hyperplasia. Endocrinology 144: 3872-3878, 2003.

15. Coppes MJ, Ye Y, Rackley R, Zhao XL, Liefers GJ, Casey G and Williams BR: Analysis of WT1 in granulosa cell and other sex cord-stromal tumors. Cancer Res 53: 2712-2714, 1993.
16. Canto P, Söderlund D, Ramón G, Nishimura E and Méndes JP: Mutational analysis of the luteinizing hormone receptor gene in two individuals with Leydig cell tumors. Am J Med Genet 108: 148-152, 2002.

17. Liu G, Duranteau L, Carel JC, Monroe J, Doyle D and Shenker A: Leydig cell tumors caused by an activating mutation of the gene encoding the luteinizing hormone receptor. N Engl J Med 341: 1731-1736, 1999

18. Looijenga LH, Gillis AJ, van Gurp RJ, Verkerk AJ and Oosterhuis JW: X inactivation in human testicular tumors. XIST expression and androgen receptor methylation status. Am J Pathol 151: 581-590, 1997.

19. Looijenga LH and Oosterhuis JW: Pathogenesis of testicular germ cell tumours. Rev Reprod 4: 90-100, 1999.

20. Iwamoto I, Yanazume S, Fujino T, Yoshioka T and Douchi T: Leydig cell tumor in an elderly patient with complete androgen insensitivity syndrome. Gynecol Oncol 96: 870-872, 2005.

21. Rosenberg C, Schut TB, Mostert M, Tanke H, Raap A, Oosterhuis JW and Looijenga L: Chromosomal gains and losses in testicular germ cell tumors of adolescents and adults investigated by a modified comparative genomic hybridization approach. Lab Invest 79: 1447-1451, 1999.

22. Looijenga LH and Oosterhuis JW: Clinical value of the $X$ chromosome in testicular germ-cell tumours. Lancet 363: 6-8, 2004.

23. Verdorfer I, Rogatsch H, Tzankov A, Steiner H and Mikuz G: Molecular cytogenetic analysis of human spermatocytic seminomas. J Pathol 204: 277-281, 2004.

24. Kawakami T, Okamoto K, Sugihara H, Hattori T, Reeve AE, Ogawa $\mathrm{O}$ and Okada Y: The roles of supernumerical X chromosomes and XIST expression in testicular germ cell tumors. J Urol 169: 1546-1552, 2003.

25. Alvarez S, MacGrogan D, Calasanz MJ, Nimer SD and Jhanwar SC: Frequent gain of chromosome 19 in megakaryoblastic leukemias detected by comparative genomic hybridization. Genes Chrom Cancer 32: 285-293, 2001.

26. Zielenska M, Bayani J, Pandita A, Toledo S, Marrano P, Andrade J, Petrilli A, Thorner P, Sorensen P and Squire JA: Comparative genomic hybridization analysis identifies gain of $1 \mathrm{p} 35 \sim \mathrm{p} 36$ and chromosome 19 in osteosarcoma. Cancer Genet Cytogenet 130: 14-21, 2001.

27. Bertram KA, Bratloff B, Hodges GF and Davidson H: Treatment of malignant Leydig cell tumor. Cancer 68: 2324-2329, 1991.

28. Mati W, Lam G, Dahl C, Thorup Andersen J and Balslev E: Leydig cell tumour - a rare testicular tumour. Int Urol Nephrol 33: 103-105, 2002. 